\title{
What to do with an asymptomatic thrombus associated with cardioverter-defibrillator lead?
}

\author{
Jak należy postapić z bezobjawową skrzepliną na elektrodzie \\ defibrylującej?
}

Mateusz Tajstra ${ }^{1}$, Mariusz Gasior ${ }^{1}$, Krzysztof Filipiak², Lech Polonski ${ }^{1}$, Marian Zembala $^{2}$

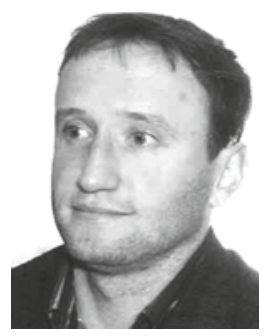

${ }^{1} 3^{\text {rd }}$ Department of Cardiology, Silesian Centre for Heart Diseases, Medical University of Silesia, Zabrze, Poland

${ }^{2}$ Department of Cardiac Surgery and Transplantology, Silesian Centre for Heart Diseases, Medical University of Silesia, Zabrze, Poland

Kardiochirurgia i Torakochirurgia Polska 2012; 3: 383-385

\begin{abstract}
A 35-year-old woman received an implantable cardioverterdefibrillator (ICD) for primary prevention of sudden cardiac death. One day after implantation, transesophageal echocardiography (TEE), carried out before defibrillation threshold testing, revealed a large, mobile, grape-shaped mass attached to the defibrillator lead in the right atrium (RA), fortunately with no symptoms. Anticoagulant therapy was started immediately. Serial TEE demonstrated that, although still asymptomatic, the RA mass was enlarged. Accordingly, thrombectomy, lead extraction and placement of an epicardial ICD lead were performed. Correct pacing and defibrillation thresholds were obtained. The patient was discharged 4 days later and during 1 month follow-up remained in good condition with no recurrence of RA thrombosis.
\end{abstract}

Key words: pacing complications; lead thrombosis.

\section{Introduction}

The number of patients who receive an implantable pacemaker or cardioverter-defibrillator (ICD) is increasing continuously. Lead-induced venous thrombosis after transvenous placement of these devices is well known [1-3]. Intracardiac thrombosis is a less frequent complication, with a range of clinical manifestations and treatment options $[4,5]$. This report describes a rare case of asymptomatic, right atrial (RA) thrombosis, related to the defibrillator lead, diagnosed 24 hours after implantation.

\section{Case Report}

A 35-year-old woman with chronic heart failure, New York Heart Association (NYHA) class III, due to dilated cardiomyopathy recognized 2 years earlier, was admitted

\section{Streszczenie}

U 35-letniej chorej implantowano kardiowerter-defibrylator w ramach profilaktyki pierwotnej nagłego zgonu sercowego. Dzień po zabiegu w echokardiograficznym badaniu przezprzełykowym wykazano na poziomie prawego przedsionka dużą ruchomą skrzeplinę związaną z elektrodą defibrylującą, bez konsekwencji klinicznych. Natychmiastowo włączono terapię przeciwkrzepliwą. W seryjnie wykonywanych badaniach TEE obserwowano zwiększanie się rozmiaru skrzepliny. Zadecydowano o chirurgicznej trombektomii, usunięciu elektrody oraz naszyciu defibrylującej elektrody nasierdziowej. Chorą wypisano 4 dni później. W okresie miesiąca pozostawała w dobrym stanie ogólnym, nie stwierdzono nawrotu skrzepliny.

Słowa kluczowe: powikłania związane ze stymulacją, skrzeplina na elektrodzie.

to our hospital to assess suitability for orthotopic heart transplantation. An electrocardiogram (ECG) showed sinus rhythm with QRS duration of 110 ms. Transthoracic echocardiography (TTE) showed ejection fraction (EF) = $20 \%$. Coronary angiography showed no coronary artery disease. There were no sinus or conduction disturbances in 24-hour ECG recording, although non-sustained ventricular tachycardia was documented. Maximal oxygen uptake volume $\left(\mathrm{VO}_{2} \max \right)$ was $14 \mathrm{ml} / \mathrm{kg} / \mathrm{min}$. Based on the obtained results, the patient was qualified for ICD implantation. The defibrillator lead was located in the right ventricular apex. Symptoms of transient ischemic attack (TIA) were observed during the implantation procedure; all neurological symptoms reversed after the procedure. One day later, before defibrillation threshold assessment,

Address for correspondence: Mateusz Tajstra, Silesian Centre for Heart Diseases, ul. Szpitalna 2, 41-800 Zabrze; Poland, tel. +48 3237336 74, fax +48 3227326 79; E-mail: mateusztajstra@wp.pl 
transesophageal echocardiography (TEE) was performed to exclude a connection between the right and left sides of the heart. TEE showed a large, mobile, grape-shaped mass, attached to the defibrillator lead in the right atrium (RA), with no septal defects or patent foramen ovale (Fig. 1). Computed tomography (CT) also showed an RA mass, but with no vein thrombosis or pulmonary embolism $(\mathrm{PE})$. The results of laboratory examinations were: leukocyte count 7500/mm; hemoglobin $12.5 \mathrm{~g} / \mathrm{dl}$; platelet count $22.5 \times 104 / \mathrm{mm}$, creatinine $0.81 \mathrm{mg} / \mathrm{dl}$, sodium $132 \mathrm{mEq} / \mathrm{l}$ and potassium $4.1 \mathrm{mEq} / \mathrm{l}$. D-dimer was slightly increased $(0.8 \mu \mathrm{g} / \mathrm{ml})$. Antinuclear antibodies, indicators of inflammation and blood culture, were negative.

Anticoagulant therapy with unfractionated heparin was started immediately, monitored using the activated partial thromboplastin time. Nevertheless, serial TEE demonstrated that the mass in RA became enlarged, although still asymptomatic (Fig. 2). A surgical intervention was decided upon. On cardiopulmonary bypass, atriotomy revealed a clot adherent to the lead (Fig. 3). The ICD lead was cut and extracted with the adherent thrombus (Fig. 4). The ICD box and the remaining part of the lead were removed. The

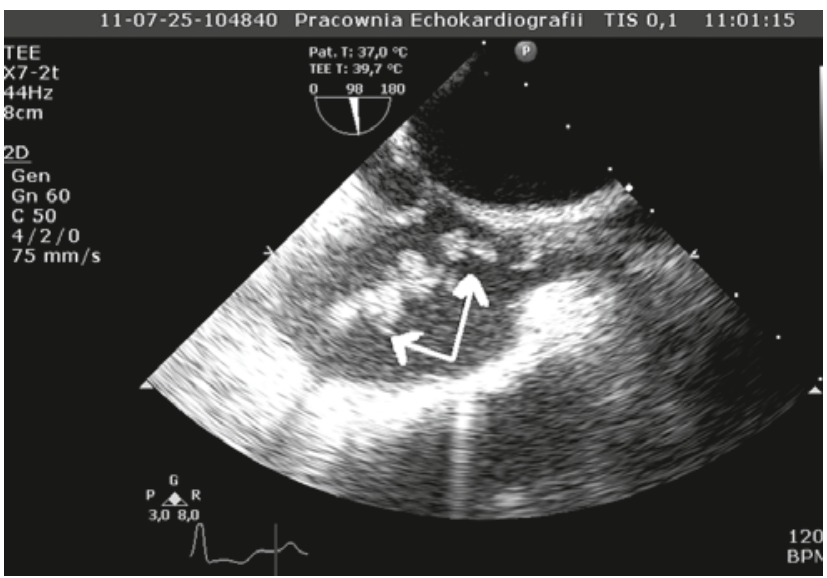

Fig. 1. Transesophageal echocardiography showed a large, mobile, grape-shaped mass, attached to the defibrillator lead in the right atrium (white arrows)

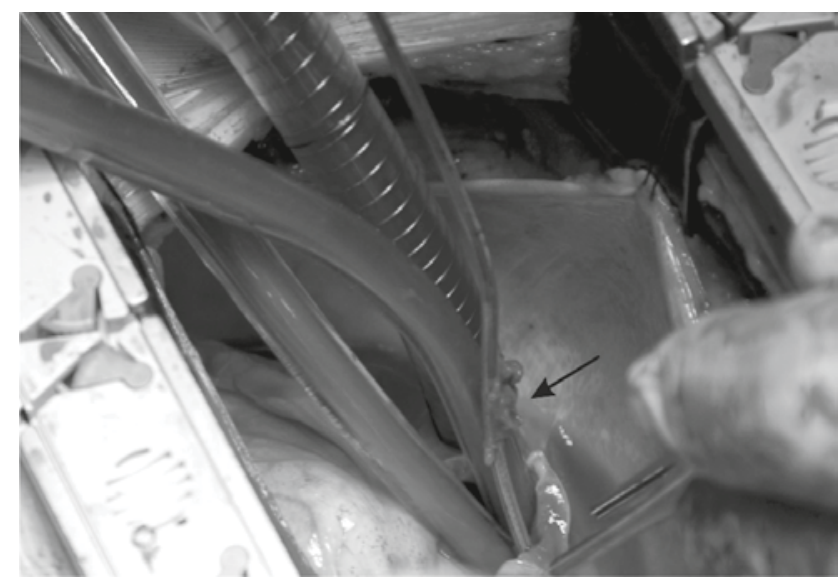

Fig. 3. Intraoperative image showing a clot adherent to the lead (black arrow) atrium was sewn and an epicardial pacing and defibrillator leads were placed. Correct pacing and defibrillation thresholds were obtained. Cultures made from the material obtained during the surgical removal were negative. The patient was discharged 4 days later and during 6-month follow-up remained in good condition without recurrence of RA thrombosis.

\section{Discussion}

In this report, we present a case of rare RA thrombosis in a young woman. The condition was diagnosed one day after ICD implantation.

Venous thrombosis associated with pacemaker leads is a well-known phenomenon that can occur in almost $20-40 \%$ of patients. Fortunately, with the development of venous collateral circulation, symptomatic vein thrombosis occurs in only $1-3 \%$ of the cases $[6,7]$. Floating intracardiac thrombi attached to the pacing lead are uncommon, but potentially very dangerous due to the high risk of PE.

Several possible mechanisms of pacemaker lead thrombosis have been postulated: the long-term presence of

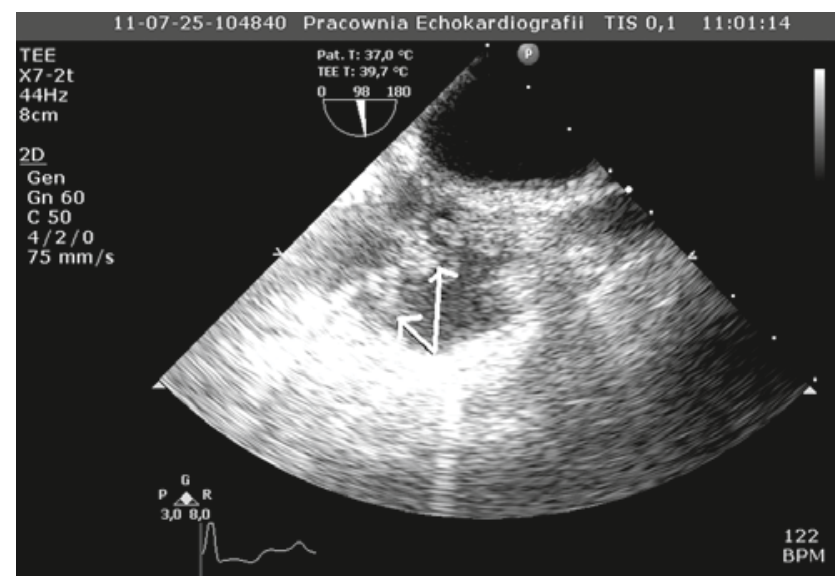

Fig. 2. Control transesophageal echocardiography revealed that the mass in the right atrium was enlarged (white arrows)

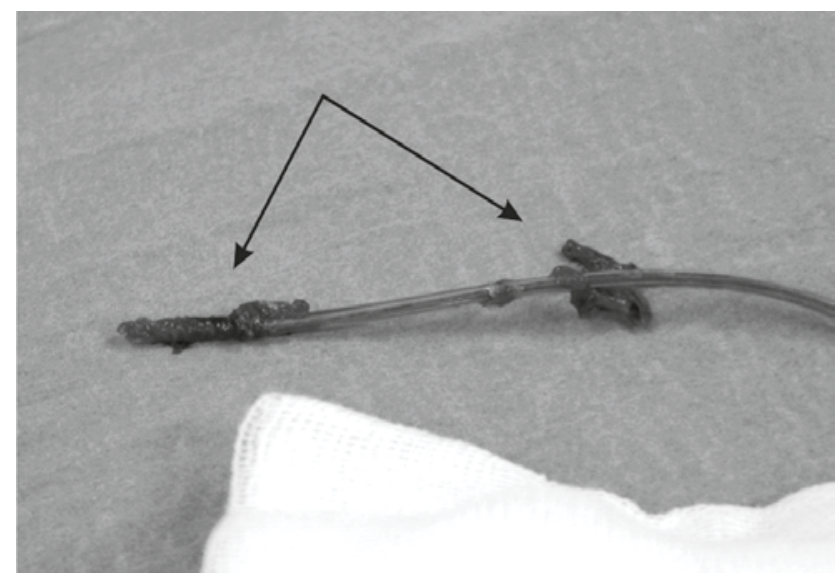

Fig. 4. The extracted lead with the adherent thrombus (black arrows) 
permanent pacemaker leads; inflammation and fibrosis alongside the lead; multiple pacemaker leads increase the total surface area for thrombus formation; another intervention (e.g. upgrade procedure), particularly within a short time frame; and thicker defibrillator leads may cause intracardiac endothelial injuries with subsequent thrombus formation. Congestive heart failure, prothrombotic states (connective tissue disease, cancer, thrombophilia, and others) or pacemaker lead injury may predispose to lead-associated thrombosis. In our patient, congestive heart failure was the most likely predisposing factor, although the time to lead thrombosis was very short. The manufacturer's expert report failed to demonstrate any damage of the implanted thrombus-related lead.

Intracardiac lead-associated thrombosis may have a variety of clinical manifestations, ranging from asymptomatic course to heart failure, shock, respiratory failure and cyanosis, edema and infectious symptoms.

There are several imaging techniques used in diagnosing intracardiac pacing lead thrombosis. TEE facilitates the exploration of cardiac structures and the great vessels without false anatomical images, which is why some authors suggest that it should be the initial imaging technique of choice in these patients. TTE, on the other hand, is a simple and widely available tool used to evaluate signs of right ventricular overload; however, it provides poor sensitivity, especially in the presence of small thrombi, which can be easily overlooked [8]. In some cases, cardioCT or percutaneous venography may be used; however, these techniques are not as available as echocardiography. Cardio-magnetic resonance is contraindicated in patients with IP and ICD.

The treatment strategy for intracardiac thrombosis associated with IP or ICD leads has been widely discussed and still remains controversial. Treatment modalities include medical management with antiplatelet and/or anticoagulation and/or thrombolysis, percutaneous intervention, surgical extraction or combined medical and interventional procedures. In our opinion, the choice of treatment should be determined by patient age, comorbidities, size, location and duration of the thrombosis and especially by the type of symptoms. Although in our patient the complication was clinically silent, surgical treatment was decided upon since a mobile thrombus carries a high risk of PE and paradoxical embolism. Additionally, despite immediate anticoagulant treatment, the thrombus became larger. Thus, in our opinion, the treatment strategy should be individualized until more clinical data are available.

\section{References}

1. Right atrial thrombus and recurrent pulmonary emboli secondary to permanent cardiac pacing - a case report and short review of literature. Angiology 1987; 38: 627-630.

2. Barakat K, Robinson NM, Spurrell RA. Transvenous pacing lead-induced thrombosis: a series of cases with a review of the literature. Cardiology 2000; 93: 142-148.

3. Carda R, Almería C, Lennie V, Serra V, Zamorano JL. What to do with an atrial thrombus? Eur J Echocardiogr 2008; 9: 204-205.

4. Cooper CJ, Dweik R, Gabbay S. Treatment of pacemaker-associated right atrial thrombus with 2-hour rTPA infusion. Am Heart J 1993; 126: 228-229.

5. Coleman DB, DeBarr DM, Morales DL, Spotnitz HM. Pacemaker lead thrombosis treated with atrial thrombectomy and biventricular pacemaker and defibrillator insertion. Ann Thorac Surg 2004; 78: e83-4.

6. Oginosawa Y, Abe H, Nakashima Y. The incidence and risk factors for venous obstruction after implantation of transvenous pacing leads. Pacing Clin Electrophysiol 2002; 25: 1605-1611.

7. van Rooden CJ, Molhoek SG, Rosendaal FR, Schalij MJ, Meinders AE, Huisman MV. Incidence and risk factors of early venous thrombosis associated with permanent pacemaker leads. J Cardiovasc Electrophysiol 2004; 15: 1258-1262.

8. Crowley JJ, Kenny A, Dardas P, Connolly DL, Shapiro LM. Identification of right atrial thrombi using transoesophageal echocardiography. Eur Heart J 1995; 16: 708-710. 